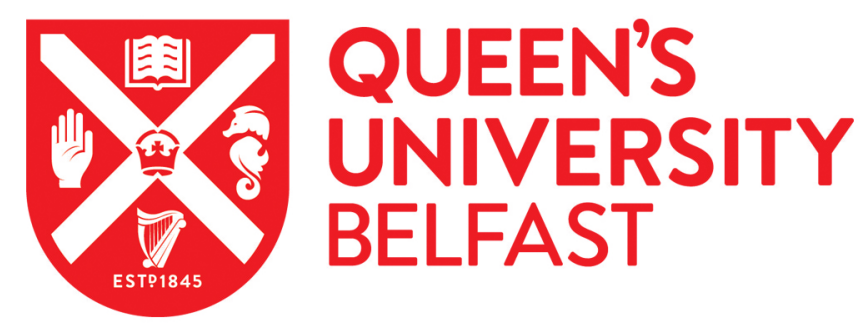

\title{
The paradox of invasion: Reeves' muntjac deer invade the British Isles from a limited number of founding females
}

Freeman, M. S., Beatty, G. E., Dick, J. T. A., Reid, N., \& Provan, J. (2016). The paradox of invasion: Reeves' muntjac deer invade the British Isles from a limited number of founding females. Journal of Zoology, 298(1), 5463. https://doi.org/10.1111/jzo.12283

Published in:

Journal of Zoology

Document Version:

Peer reviewed version

Queen's University Belfast - Research Portal:

Link to publication record in Queen's University Belfast Research Portal

Publisher rights

(c) 2015 The Zoological Society of London

This is the peer reviewed version of the following article: Freeman, M. S., Beatty, G. E., Dick, J. T. A., Reid, N. and Provan, J. (2015), The paradox of invasion: Reeves' muntjac deer invade the British Isles from a limited number of founding females. Journal of Zoology, which has been published in final form at http://onlinelibrary.wiley.com/doi/10.1111/jzo.12283/abstract. This article may be used for non-commercial purposes in accordance with Wiley Terms and Conditions for Self-Archiving

\section{General rights}

Copyright for the publications made accessible via the Queen's University Belfast Research Portal is retained by the author(s) and / or other copyright owners and it is a condition of accessing these publications that users recognise and abide by the legal requirements associated with these rights.

Take down policy

The Research Portal is Queen's institutional repository that provides access to Queen's research output. Every effort has been made to ensure that content in the Research Portal does not infringe any person's rights, or applicable UK laws. If you discover content in the Research Portal that you believe breaches copyright or violates any law, please contact openaccess@qub.ac.uk. 
The paradox of invasion: Reeves' muntjac deer invade the British Isles from a limited number of founding females

Marianne S. Freeman ${ }^{1,2}$, Gemma E. Beatty ${ }^{1,2,3}$, Jaimie T. A. Dick ${ }^{1,2,3}$, Neil Reid ${ }^{1,2,3} \&$ Jim $\operatorname{Provan}^{1,2,3^{*}}$

${ }^{1}$ School of Biological Sciences, Queen's University Belfast, Belfast BT9 7BL

${ }^{2}$ Quercus, School of Biological Sciences, Queen's University Belfast, Belfast BT9 $7 \mathrm{BL}$

${ }^{3}$ Institute for Global Food Security, Queen's University Belfast, Belfast BT9 7BL

Running title: Population genetics of invasive muntjac deer

Correspondence: Dr. Jim Provan (address as above)

Tel: +442890972280

Fax: +44 2890975877

E-mail: J.Provan@qub.ac.uk 


\section{Abstract}

3 High levels of genetic diversity and high propagule pressure are favoured by conservation

4 biologists as the basis for successful re-introductions and ensuring the persistence of

5 populations. However, invasion ecologists recognise the "paradox of invasion", as successful

6 species introductions may often be characterised by limited numbers of individuals and

7 associated genetic bottlenecks. In the present study, we used a combination of high-

8 resolution nuclear and mitochondrial genetic markers to investigate the invasion history of

9 Reeves' muntjac deer in the British Isles. This invasion has caused severe economic and

10 ecological damage, with secondary spread currently a concern throughout Europe and

11 potentially globally. Microsatellite analysis based on eight loci grouped all 176 introduced

12 individuals studied from across the species' range in the UK into one genetic cluster, and

13 seven mitochondrial D-loop haplotypes were recovered, two of which were present at very

14 low frequency and were related to more common haplotypes. Our results indicate that the

15 entire invasion can be traced to a single founding event involving a low number of females.

16 These findings highlight the fact that even small releases of species may, if ignored, result in

17 irreversible and costly invasion, regardless of initial genetic diversity or continual genetic

18 influx. 


\section{Introduction}

21 Conservation biologists have long appreciated the importance of high levels of genetic

22 diversity and high propagule pressure as the basis for the successful introduction and enhanced persistence of populations (Frankham et al. 2002). The parallel case of species invasions, however, is often characterised by limited numbers of individuals and associated genetic bottlenecks, a so-called "paradox of invasion" (Sax \& Brown 2000; Dlugosch \& Parker 2008a). Although there are several well-known cases of invasive species that exhibit extremely low levels of genetic variation (Hollingsworth \& Bailey 2000), many successful invasions have been facilitated by multiple introductions, resulting in high levels of genetic diversity in the invasive range (Lockwood et al. 2005, 2009; Lavergne \& Molofsky 2007; Roman \& Darling 2007; Simberloff 2009). In particular, we need to know if particularly damaging species are likely to establish and spread from small founder events or if high propagule pressure is required (Sax \& Brown 2000; Lockwood et al. 2005, 2009; Simberloff 2009). The use of genetic studies to gain insight into various aspects of the invasion process, such as the mode and frequency of introduction, can help predict the potential likelihood and impacts of further invasion (e.g. Provan et al. 2008; Xavier et al. 2009) and also offer information helpful for management and control (Allendorf \& Lundquist 2003).

The impacts of invasive species are of global concern (Lowe et al. 2000; Simberloff et al. 2013). Introduced deer species represent one such problem, with more than a quarter of deer species having been introduced outside of their native range (Dolman \& Waeber 2008). Overabundant deer negatively impact biodiversity (Cote et al. 2004), commercial land use

41 (Putman \& Moore1998), and human health and well-being through potentially fatal deervehicle collisions (Bruiderink \& Hazebroek 1996). The arrival of non-native deer species can impose ecological pressure on woodland ecosystems, with new species moving into 
unoccupied niches detrimentally impacting native flora and fauna (White et al. 2008). With deer introductions and secondary spread continuing, such as the arrival and establishment of muntjac throughout Ireland (Dick et al. 2010, 2012), knowledge of invasion history is critical to assess risks of future ecological and economic damage through population expansion.

Outside of their native range of south-east China and Taiwan, Reeves's Chinese muntjac (Muntiacus reevesi, Ogilby, 1839) have been introduced to France, Japan and the British Isles, though only the latter two countries now have established populations (Lever 2009; Ohdachi et al. 2009). The post-introduction natural range expansion of muntjac in the British Isles has been around $1 \mathrm{~km}$ per year, similar to other introduced deer (Chapman et al. 1994). However, their full range expansion has been supplemented by secondary innocula via human-mediated dispersal (Smith-Jones 2004). Their invasive success is further facilitated by year-round breeding, rapid reproductive maturity (Chapman et al. 1997), and an ability to inhabit anthropogenically modified habitats (Dansie, 1983). Indeed, the Game and Wildlife Conservancy Trust reported a 1,756\% increase in the numbers of muntjac shot between 19612009 (Aebische et al, 2011), with the national population estimated very conservatively at 52,250 individuals by 2008 (Harris and Yalden, 2008). This rapid dispersal and increase in abundance in such a relatively short time has resulted in considerable ecological and economic damage (Cooke \& Farrell 2001; Dolman and Waeber 2008; Mayle 2002). Browsing and grazing pressure by muntjac has had major impacts on woodland ground flora diversity and tree regeneration (Joys et al. 2004) and, as a result, there have been cascade effects on other taxa, including rare butterflies such as the heath fritillary (Melitaea athalia) and wood white (Leptidea sinapis) (Tabor 1998). The removal of ground cover by muntjac reduces nesting sites for woodland songbirds (Holt et al. 2011) and is also thought to be

67 responsible for the reduction in woodland small mammal populations (Flowerdew \& Elwood 68 2001). 
Historical information on the sourcing, supply and release of muntjac in the British Isles is

highly confusing (Chapman et al, 1994). Records indicate that a pair of Reeves' muntjac were presented to the Zoological Society of London in 1838 by John Russell Reeves, possibly sourced from Guangdong (Canton) Province, South China. In 1867, the Zoo purchased a replacement male obtained by Robert Swinhoe, possibly sourced from Formosa (also known as Chinese Taipei, or more commonly now, Taiwan, which has its own subspecies known as Taiwanese Reeves's muntjac Muntiacus reevesi micrurus). The female died shortly after giving birth and was replaced in 1873 with a female from Ningpo. The species is known to have bred at the London Zoo during this period. In November 1874, another pair from Formosa (also known as Chinese Taipei, or more commonly now, Taiwan, which has its own subspecies known as Taiwanese Reeves's muntjac Muntiacus reevesi micrurus) were presented to the Zoological Society of London and, in the same year, a further female was sent from Ningpo and a male from Hong Kong, with the parents of the latter believed to have originated from Formosa (Sclater, 1875). Out of the 14 births that were recorded at London Zoo between 1874 and 1881, nine were sold to Tring Park, England, and Jardin des Plants, France, amongst other possible locations and between 1890 and 1928 no records of muntjac in London Zoo exist (Chapman et al 1994).

Woburn Abbey had an initial import of three pairs of muntjac from a dealer on three separate occasions in 1893 (Chapman et al. 1994). These individuals may have come direct from wild caught animals in China, but it is likely that they were captive-bred individuals, as, by this time, at least six other collections were known to keep and trade muntjac in Europe, including Rambouillet, France (Dansie, 1983) and Berlin Zoo, Germany (Chapman et al. 1994). The $11^{\text {th }}$ Duke of Bedford was also well known for travelling around Europe collecting deer for his park in Woburn Abbey (Dansie, 1983). What is known is that he received a male and two females, most likely of the London Zoo descendents, from Jardin 
94 des Plants in 1902 (Chapman et al 1994). In total between 1894 and 1906, 13 males and 15

95 females were brought into Woburn Park and records show that eleven individuals were released from there in 1901 (Chapman 1993).

$$
\text { Until 2009, it was widely assumed that muntjac had not reached Scotland or Ireland }
$$

(Lever 2009). Recent deer surveys, however, suggest that muntjac have spread westward into Wales and south-west England as well as northward up the eastern half of England to the Scottish Borders (Ward et al. 2008), and most recently have been discovered in Ireland (Hailstone 2012). The first confirmed sighting of muntjac in the wild in the Republic of Ireland was a culled animal in Co. Wicklow (Carden et al. 2011), swiftly followed by a carcass from a deer-vehicle collision in Co. Down, Northern Ireland (Dick et al. 2010). The question remains, however, as to the size of the actual founding 'propagule' that led to this dramatic and continuing invasion of the British Isles. Such information is important to help undertstand and predict invasion success in general and with regards to the likelihood of further invasions by non-native deer globally.

$$
\text { In the only population genetic analysis of muntjac in Britain carried out to date, it was }
$$
suggested that there were at least eight maternal lineages, and most likely more, based on restriction fragment length polymorphism (RFLP) analysis of the mitochondrial genome (Williams et al. 1993). However, mitochondrial markers only give an indication of femalemediated gene flow, and analysis of high-resolution nuclear microsatellite markers offers a more complete picture of the invasion history of a species (Guillemaud et al. 2010).

Consequently, in the present study we carried out a combined analysis using microsatellites and sequencing of the mitochondrial D-loop region to resolve the invasion history of the species in the British Isles, specifically the likely number of founding females. 


\section{Sampling and DNA extraction}

120 Tissue samples were collected from 176 muntjac across the majority of their known

121 distribution in the British Isles (Figure 1; Table 1; Appendix 1). Samples were collected as

122 part of ongoing control programme by deer managers from the British Deer Society (BDS).

123 Tissue samples, mostly tongue or ear clippings $\left(1 \mathrm{~cm}^{3}\right)$, were collected and stored in absolute

124 ethanol. In addition, five DNA samples of the Taiwanese subspecies Muntiacus reevesi

125 micrurus were obtained directly from Taiwan. DNA was extracted from tissue samples using 126 a high salt extraction technique (Aljanabi \& Martinez 1997).

\section{Genotyping}

129 All samples were genotyped for eight microsatellite loci originally developed for $M$.

130 crinifrons (Wu et al. 2008): Mcr-3, Mcr-4, Mcr-5, Mcr-6, Mcr-7, Mcr-13, Mcr-14 and Mcr-

131 19. The remaining three loci reported by Wu et al. (2008) could not be amplified reliably.

132 PCR was carried out in a total volume of $10 \mu 1$ containing $100 \mathrm{ng}$ genomic DNA, 5 pmol of 6-FAM-labelled M13 primer, 0.5 pmol of M13-tailed forward primer, 5 pmol reverse primer,

134 1x PCR reaction buffer, $200 \mu \mathrm{M}$ each dNTP, $2.5 \mathrm{mM} \mathrm{MgCl}_{2}$ and $0.25 \mathrm{U}$ GoTaq Flexi DNA

135 polymerase (Promega, Sunnyvale, CA, USA). PCR was carried out on a MWG Primus

136 thermal cycler (Ebersberg, Germany) using the following conditions: initial denaturation at

$13794{ }^{\circ} \mathrm{C}$ for $3 \mathrm{~min}$ followed by 40 cycles of denaturation at $94{ }^{\circ} \mathrm{C}$ for $30 \mathrm{~s}$, annealing at $55{ }^{\circ} \mathrm{C}$

138 for $30 \mathrm{~s}$, extension at $72{ }^{\circ} \mathrm{C}$ for $30 \mathrm{~s}$ and a final extension at $72{ }^{\circ} \mathrm{C}$ for $5 \mathrm{~min}$. Genotyping was

139 carried out on an AB3730xl capillary genotyping system. (Life Technologies; Carlsbad,

140 California, USA). Allele sizes were scored using the GENEMAPPER software package (v4.1; 
141 Applied Biosystems) using LIZ-500 size standards, and were checked by comparison with

142 previously sized control samples. All chromatograms were inspected visually.

\section{Mitochondrial D-loop sequencing}

145 The complete mitochondrial D-loop region was amplified using a pair of primers designed

146 from the complete mitochondrial genome of $M$. reevesi (GenBank accession number

147 AF527537): trn-Pro-F 5'-TCAACACCCAAAGCTGAAGTT-3 and trn-Phe-R 5'-

148 TCAGTGCCTTGCTTTATTGC-3. PCR was carried out in a total volume of $20 \mu 1$

149 containing $200 \mathrm{ng}$ genomic DNA, 10 pmol of each primer, 1x PCR reaction buffer, $200 \mu \mathrm{M}$

150 each dNTP, $2.5 \mathrm{mM} \mathrm{MgCl}_{2}$ and $0.5 \mathrm{U}$ GoTaq Flexi DNA polymerase (Promega, Sunnyvale,

151 CA). PCR was carried out on a MWG Primus thermal cycler (Ebersberg, Germany) using the

152 following parameters: initial denaturation at $94{ }^{\circ} \mathrm{C}$ for $3 \mathrm{~min}$ followed by 40 cycles of

153 denaturation at $94{ }^{\circ} \mathrm{C}$ for $30 \mathrm{~s}$, annealing at $58^{\circ} \mathrm{C}$ for $30 \mathrm{~s}$, extension at $72{ }^{\circ} \mathrm{C}$ for $1 \mathrm{~min}$ and a

154 final extension at $72{ }^{\circ} \mathrm{C}$ for 5 min. Five $\mu 1$ PCR product were resolved on $1.5 \%$ agarose gels

155 and visualised by ethidium bromide staining, and the remaining $15 \mu \mathrm{l}$ were EXO-SAP

156 purified and sequenced in both direction using the BigDye sequencing kit (V3.1; Applied

157 Biosystems) using the primers Munt-DLOOP-IN-F 5'-ATCCTTGTCAACATGCGTATC-3'

158 and Munt-DLOOP-IN-R 5'-TTATGTGTGAGCATGGGCTG-3' and run on an AB 3730XL

159 DNA analyser (Life Technologies; Carlsbad, California, USA).

160

161 Data analysis

162 GENEPOP (V3.4; Raymond and Rousset, 1995) was used to test for linkage disequilibrium

163 between nuclear microsatellite loci. MICRO-CHECKER (van Oosterhout et al. 2004) was

164 used to check for the possible occurrence of null alleles. To estimate genetic diversity within

165 populations containing six or more individuals (Table 1), levels of observed $\left(H_{O}\right)$ and 
166 expected $\left(H_{E}\right)$ heterozygosity, levels of allelic richness $\left(A_{R}\right)$ and fixation indices $\left(F_{I S}\right)$ were

167 calculated using the FSTAT software package (V2.9.3.2; Goudet, 2001). Significance of $F_{I S}$

168 was determined by 10,000 randomisation steps. Levels of genetic diversity $(H)$ based on

169 mtDNA D-loop haplotype frequencies were calculated using the ARLEQUIN software package

$170 \quad$ (V3.5.1.2; Excoffier and Lischer, 2010).

171 The overall level of genetic differentiation between populations was estimated using $\Phi_{\mathrm{ST}}$,

172 which gives an analogue of $F_{\mathrm{ST}}$ (Weir and Cockerham, 1984) calculated within the analysis

173 of molecular variance (AMOVA) framework (Excoffier et al. 1992) using ARLEQUIN. To

174 further identify possible patterns of genetic structuring, the software package BAPS (V5;

175 Corander et al. 2003) was used to identify clusters of genetically similar populations based on

176 the complete microsatellite data set (181 individuals) using a Bayesian approach. Ten

177 replicates were run for all possible values of the maximum number of clusters $(K)$ up to $K=$

17840 , with a burn-in period of 10,000 iterations followed by 100,000 iterations. Multiple

179 independent runs always gave the same outcome. To further identify possible spatial patterns

180 of gene flow, a principal coordinate analysis (PCA) was carried out on the population-level

181 data set (105 individuals; Table 1) in GENALEx (V6.1; Peakall \& Smouse 2006). Inter-

182 individual genetic distances were calculated as described in Smouse \& Peakall 1999, and the

183 PCA was carried out using the standard covariance approach.

184 To test for the occurrence of a genetic bottleneck, the Wilcoxon test for heterozygote

185 excess was performed under the infinite alleles model (IAM), the stepwise mutation model

186 (SMM) and a two-phase model (TPM) incorporating 90\% single-stepwise mutations using

187 the program BotTLENECK (V1.2; Piry et al. 1999). The Wilcoxon test was used as it is

188 recommended for less than 20 microsatellite loci. 
191 No evidence of linkage disequilibrium was detected between any of the eight nuclear

192 microsatellites analysed. Between eight (Mcr-3) and 16 (Mcr-5) alleles were detected per

193 locus, with a total of 98 (mean $=12.25$ per locus). Within populations for which a minimum

194 of six individuals were sampled, levels of allelic richness $\left(A_{\mathrm{R}}\right)$ averaged over loci ranged

195 from 3.723 (Kineton) to 5.120 (Sandlings), with a mean value of 4.136 (Table 2). Levels of

196 observed $\left(H_{\mathrm{O}}\right)$ and expected $\left(H_{\mathrm{E}}\right)$ heterozygosity ranged from 0.450 (Welford) to 0.663

197 (Wytham Wood; mean $=0.558)$, and from $0.675($ Kineton $)$ to 0.855 (Sandlings; mean $=$

198 0.755) respectively. The heterozygote deficit observed in the majority of the populations gave

199 rise to $F_{\text {IS }}$ values which were significantly different from zero in all of the populations

200 studied, ranging from 0.140 (Wytham Wood) to 0.420 (Welford; mean $=0.270$ ), which is

201 consistent with the departure from Hardy-Weinberg equilibrium generally associated with

202 invasive species. MICRO-CHECKER indicated the possibility of null alleles at four of the eight loci (Mcr-5, Mcr-7, Mcr-13 and Mcr-14), which could at least in part explain this heterozygosity deficit.

Complete D-loop sequences were obtained for 121 individuals, with an alignment length of 815 bp. A total of 23 substitution mutations gave rise to seven haplotypes (Figure 2). No indels were observed, which can often make the alignment of D-loop sequences difficult. There was a notable east-west cline in the frequency of haplotypes (Figure 1). Haplotype diversity values for populations for which a minimum of six individuals were sampled ranged

210 from zero (Ickworth Park, for which only two complete sequences were obtained) to 0.800

211 (Sennowe Park; mean $=0.430)$. As the mitochondrial D-loop region exhibits an extremely

212 fast mutation rate, and thus provides a high-resolution marker for female lineages, since the mitochondrial genome is maternally inherited in mammals (Harrison 1989), the results 
214 indicate a low number of founding females. Two of the seven haplotypes occurred at very

215 low frequency. All seven haplotypes were split into four very divergent groups, each

216 separated by at least seven mutations. It is possible that Haplotype H6 evolved from

217 Haplotype $\mathrm{H} 2$ after the introduction, since the two differ by a single mutation, although it is

218 difficult to be more certain in the absence of an accurate mutation rate for this region.

219 Likewise, Haplotype H7 is only found in a single individual and is one mutation removed

220 from Haplotype H5, suggesting very recent divergence.

221 The overall level of differentiation estimated by nuclear microsatellites was low $\left(\Phi_{\mathrm{ST}}=\right.$

$2220.050, P<0.001$ ), whilst the level based on mitochondrial D-loop sequences was much

223 higher $\left(\Phi_{\mathrm{ST}}=0.470, P<0.001\right.$; Table 2$)$. The BAPS analysis indicated that all the

224 individuals analysed from Britain and Ireland were grouped into a single genetic cluster

225 (100\% probability), separate from the Taiwanese subspecies Muntiacus reevesi. This was

226 reflected in the PCA, which showed no evidence of geographical structuring of individual

227 multilocus genotypes (Figure 3). Finally, the Wilcoxon test for heterozygote excess

228 suggested a bottleneck under the IAM $(P=0.006)$, but not under the SMM or the TPM,

229 although it should be borne in mind that the number of loci used (eight) may be insufficient 230 to detect the latter (see Discussion). 


\section{Discussion}

233 The probability of invasion success generally increases with propagule pressure, in terms of a

234 high number of viable founding individuals and repeated introductions (Simberloff 2009).

235 However, we also know that some invasions appear to establish from small founding events,

236 including the well-known case of the green seaweed Caulerpa taxifolia, which spread

237 throughout the Mediterranean rapidly following a single aquarium release (Jousson et al.

238 1998), and the suggestion that a single pair of squirrels would have a greater than $50 \%$

239 chance of establishing a new population (Bertolino 2009). However, the invasion history of

240 many alien species is unknown. Resolving the size of founding propagules of major invasions

241 could help predict future invasions. Here, the use of high-resolution microsatellite markers

242 suggested that the invasion of the British Isles by Chinese Reeve's muntjac resulted from a

243 very small founding population. Indeed, our analysis is not only consistent with the known

244 introduction history of muntjac, but implies, through combined nuclear and mtDNA data, that

245 the current population was founded by a single group including a low number of females.

246 From Chapman et al. (1994), it seems probable to suggest those females are descendents of

247 some of the original five females imported to London Zoo amongst others imported

248 elsewhere.

249 The distribution of mtDNA haplotypes across southeast England is consistent with

250 separate escapes and releases from Woburn and other captive collections, since Haplotypes

$251 \mathrm{H} 2$ and $\mathrm{H} 3$, represented in yellow and blue respectively, tend to be primarily found west of

252 Woburn, which lies just northwest of Site 4 in Figure 1, and indeed are the only two

253 haplotypes found in this area, consistent with an extreme maternal founder effect. Likewise,

254 Haplotypes H1 and H4, shown in red and green, are not found west of Woburn, and are the

255 dominant haplotypes in sites to the east. The only previous genetic study on muntjac in the 
UK suggested "at least eight maternal lineages in the UK" (Williams et al. 1993). This was based on RFLP analysis of the same D-loop region analysed in the present study, but this approach, unlike the sequencing analysis carried out here, cannot elucidate the genetic relationships between haplotypes. Three of the eight haplotypes detected by Williams et al.

260 (1993) occurred at frequencies of $1.7 \%, 0.5 \%$ and $0.25 \%$ and could, as in the present study, represent recent, post-introduction mutations. However, the lack of information on the genealogical relationships between the RFLP haplotypes meant that this aspect could not be addressed in the earlier study, but their identification of four or five haplotypes at relatively high frequency ( $5 \%$ or above) is consistent with our findings, particularly when considering that they analysed over three times as many samples. It is difficult to quantify accurately the number of females involved in the introduction, since many of the original mitochondrial lineages may have become extinct since the original founding event, but both studies indicate a low number of individuals. The additional use of high-resolution microsatellite markers in the present study suggests a single introduction of muntjac into the Britain Isles, since levels of genetic differentiation were very low. As invasion events, single or multiple, are generally characterised by founder effects, the random nature of these episodes means that multiple events tend to involve separate gene pools from the original source population (Provan et al. 2005). This is contrary to the assignment of all individuals sampled from Britain and Ireland in the present study to a single genetic cluster in the BAPS analysis, and the lack of any geographical structuring in the PCA. The results of the BOTTLENECK analysis were somewhat inconclusive, with a genetic bottleneck suggested under the IAM but not under the other two models. This could be due to the fact that the two models that assume stepwise mutation, particularly the SMM, are more conservative than the IAM (Cornuet and Luikart 1996; Luikart and Cornuet 1998). Alternatively, it may be that the short generation time of muntjac, which can start breeding at around 36 weeks (Chapman et al. 1997), means that 
281 sufficient generations have passed since introduction to mask the signature of any genetic bottleneck.

283 Our findings highlight the risk of directly equating propagule pressure with the success of 284 an invasion, since, despite a potentially high number of released individuals across multiple 285 sites, the data here show that the invasion is descended from the same import source which 286 consisted of a limited number of founders. Given that invasive deer species have been found 287 to have earlier weaning and sexual maturity age (Fautley et al. 2012), the success of muntjac invasion undoubtedly appears to be due their high fecundity and rate of increase in the initial stages, as well as secondary introductions at multiple locations over a sustained period of time. However, instead of offering a chance for an increase in genetic variation, due to the restricted original gene pool, the sole advantage of these multiple release sites appears to be demographic, by offering additional mates if a nearby population begins to fail. Invasion success, in spite of population bottlenecks, has previously been reported in species once kept as exotic pets or decorative plants (Le Page et al. 2000; Goodman et al. 2001; Dlugosch \& Parker 2008b). It is possible that human-mediated species introductions such as those from ornamental and/or pet species have an increased chance of invasion due to ex-situ breeding, despite low genetic diversity and limited primary introductions from the native range. conservation reintroductions. Though low genetic diversity is not considered ideal in species

300 reintroduction programmes (Frankham et al. 2002), this study supports the idea that a

301 successful introduction can result from a low number of individuals with limited genetic variation. Many examples of successful reintroductions from low number of founding individuals exist. Taylor et al. (2005) found that the number of released New Zealand saddlebacks (Philesturnus carunculatus) and robins (Petroica australis) on different islands

305 did not affect the success of introductions. The alpine ibex (Capra ibex ibex), carefully bred 
in captivity from a very low number of founding individuals, was reintroduced successfully on several occasions (Stüwe \& Nievergelt 1991). Most notably, the mílù (Elaphurus davidianus), also known as Père David's deer, was successfully reintroduced to China having been rescued from just two females and a single male after careful captive breeding by the

$31011^{\text {th }}$ Duke of Bedford (Zeng et al. 2007). In all cases, success was based on a combination of 311 selective breeding to increase the effective captive population size and multiple releases.

312 Conversely, our paper offers an insight for legislative policy in invasive species management. Our data are consistent with four or five females leading to a major geographic

314 invasive species problem. This should serve as a warning for future muntjac invasions, such

315 as those unfolding in Ireland currently (Dick et al. 2010; Freeman et al. 2011; Dick et al.

316 2012; Hogg et al. 2014) and a suspected introduction in Belgium (T. Adrianens, pers.

317 comm.). It appears quite plausible that, in both cases, muntjac could colonise a large area,

318 giving rise to large numbers of individuals, from relatively few founding individuals. We

319 raise the point to caution against complacency if invasive species such as muntjac are

320 suspected in a new area and we would advocate heightened biosecurity and a need to react to

321 sightings rapidly (Caffrey et al. 2014). Indeed, under recent EU legislation, inclusion of muntjac on the list of high-risk species would restrict the movement and release of the species (Genovesi et al. 2014). The present study is an example of the value of genetics to invasion ecology, and also helps to illuminate the origin of muntjac deer populations in the

325 British Isles. Vigilance should be exercised even with small releases of species such as

326 muntjac, which may, if ignored, result in an irreversible invasion, regardless of initial genetic diversity or continuous genetic influx. 


\section{Acknowledgements}

330 Marianne Freeman was supported by Department of Employment and Learning (DEL) and

331 Neil Reid was supported by the Natural Heritage Research Partnership (NHRP) between the

332 Northern Ireland Environment Agency (NIEA) and Quercus, Queen's University Belfast

333 (QUB). We are grateful to the members of the BDS for taking the time to send tissue samples

334 and to Kurtis Pei (Professor of Wildlife Ecology \& Management, National Pingtung

335 University of Science \& Technology, Taiwan) for the M. reevesi micrurus samples. Required

336 permits for the export of samples from Taiwan were obtained from the Council of Agriculture

337 and import to the UK from the Department for Environment, Food and Rural Affairs

338 (Authorisation number POAO/2010/151). We are also grateful to Doug Armstrong and an

339 anonymous reviewer, whose comments improved the manuscript. 


\section{References}

342 Aebischer, N.J., Davey, P.D. \& Kingdon, N.G. (2011). National Gamebag Census: Mammal

343 Trends to 2009. Game \& Wildlife Conservation Trust, Fordingbridge

344 (http://www.gwct.org.uk/ngcmammals)

345 Allendorf, F.W. \& Lundquist, L.L. (2003). Introduction: population biology, evolution and

346 control of invasive species. Conservation Biology 17, 24-30.

347 Aljanabi, S.M. \& Martinez, I. (1997). Universal and rapid salt-extraction of high quality

348 genomic DNA for PCR-based techniques. Nucleic Acids Research 25, 4692-4693

349 Bertolino, S. (2009) Animal trade and non-indigenous species introduction: the world-wide

$350 \quad$ spread of squirrels. Diversity and Distributions 15, 701-708.

351 Bruiderink, G.W.T.A.G. \& Hazebroek, E. (1996). Ungulate traffic collisions in Europe.

352 Conservation Biology 10, 1059-1067.

353 Caffrey, J.M., Baars, J., Barbour, J.H., Boets, P., Boon, P., Davenport, K., Dick, J.T., Early,

354 J., Edsman, L. \& Gallagher, C. (2014). Tracking invasive alien species in Europe: the top

35520 issues. Mangement of Biological Invasions 5, 1-20.

356 Carden, R.F., Carlin, C.M., Marnell, F., McElholm, D., Hetherington, J. \& Gammell, M.P.

357 (2011). Distribution and range expansion of deer in Ireland. Mammal Review 41, 313-325.

358 Chapman, N.G. (1993). Current distribution, status and habitat preferences of Reeves'

359 muntjac. in Mayle BAE ed (1993) Muntjac Deer; Their Biology, Impact and Management

360 in Britain. Forestry Commission, Farnham and British Deer Society, Trentham.

361 Chapman, N., Harris, S. \& Stanford, A. (1994). Reeves' muntjac, Muntiacus reevesi, in

362 Britain - their history, spread, habitat selection, and the role of human intervention in

363 accelerating their dispersal. Mammal Review 24, 113-160. 
364 Chapman, N.G., Furlong, M. \& Harris, S. (1997). Reproductive strategies and the influence

365 of date of birth on growth and sexual development of an aseasonally - breeding ungulate:

366 Reeves' muntjac (Muntiacus reevesi). Journal of Zoology 241, 551-570.

367 Cooke, A. \& Farrell, L. (2001). Impact of muntjac deer (Muntiacus reevesi) at Monks Wood 368 National Nature Reserve, Cambridgeshire, eastern England. Forestry 74, 241.

369 Corander, J., Waldmann, P. \& Sillanpää, M.J. (2003). Bayesian analysis of genetic

370 differentiation between populations. Genetics 163, 367-374.

371 Cornuet, J-M. \& Luikart, G. (1996). Description and power analysis of two tests for detecting 372 recent population bottlenecks from allele frequency data. Genetics 144, 2001-2014.

373 Cote, S.D., Rooney, T.P., Tremblay, J.P., Dussault, C. \& Waller, D.M. (2004). Ecological 374 impacts of deer overabundance. Annual Review of Ecology, Evolution and Systematics 35, $375 \quad 113-147$.

376 Dansie, O. (1983) Muntjac. In: Muntjac and Chinese Water Deer. pp 3-24. The British Deer 377 Society, Warminster, UK.

378 Dick, J.T.A., Freeman, M., Provan, J. \& Reid N. (2010). First record of free-living Reeves' 379 muntjac deer (Muntiacus reevesi Ogilby, 1939) in Northern Ireland. Irish Naturalists' $380 \quad$ Journal 31, 151.

381 Dick, J.T.A., McKillen, J., Chapman, N., Collins, L., Provan, J., Freeman, M., Hogg, K., 382 Reid, N. (2012). Post-mortem Examination of a Wild Muntjac from Northern Ireland. 383 Report prepared by the Natural Heritage Research Partnership (NHRP) between Quercus, 384 Queen's University Belfast, and the Northern Ireland Environment Agency (NIEA).

385 Northern Ireland Environment Agency Research and Development Series No 12/12, 386 Belfast, UK. 
Dlugosch, K.M. \& Parker, I.M. (2008a) Founding events in species invasions: genetic variation, adaptive evolution, and the role of multiple introductions. Molecular Ecology 17, 431-449.

Dlugosch, K.M. \& Parker, I.M. (2008b) Invading populations of an ornamental shrub show rapid life history evolution despite genetic bottlenecks. Ecology Letters 11, 701-709.

Dolman, P.M. \& Waeber, K. (2008). Ecosystem and competition impacts of introduced deer. Wildlife Research 35, 202-214.

394 Excoffier, L., Smouse, P.E. \& Quattro, J.M. (1992). Analysis of molecular variance inferred from metric distances among DNA haplotypes - application to human mitochondrial DNA restriction data. Genetics 131, 479-491.

397 Excoffier, L. \& Lischer, H.E.L. (2010). ARLEQUIN suite ver 3.5: a new series of programs to perform population genetics analyses under Linux and Windows. Molecular Ecology Resources 10, 564-567.

400

Fautley, R., Coulson, T. \& Savolainen, V. (2012) A comparative analysis of the factors promoting deer invasion. Biological Invasions 14, 2271-2281.

402 Flowerdew, J. \& Ellwood, S. (2001) Impacts of woodland deer on small mammal ecology. Forestry 74, 277.

404 Frankham, R., Briscoe, D.A. \& Ballou, J.D. (2002). Introduction to Conservation Genetics. 405 Cambridge University Press, London, UK.

406 Freeman, M., Reid, N. \& Dick, J.T.A. (2011) Evaluation of the Veracity of Anecdotal 407 Muntjac Records in Northern Ireland. Report prepared by the Natural Heritage Research 408 Partnership (NHRP) between Quercus, Queen's University Belfast, and the Northern 409 Ireland Environment Agency (NIEA). Northern Ireland Environment Agency Research $410 \quad$ and Development Series No 11/07, Belfast, UK. 
411 Genovesi P., Carboneras C., Vilà M. \& Walton P. (2014) EU adopts innovative legislation on

412 invasive species: a step towards a global response to biological invasions? Biological

$413 \quad$ Invasions 17, 1307-1311.

414 Goodman, S.J., Tamate, H.B., Wilson, R., Nagata, J., Tatsuzawa, S., Swanson, G.M.,

415 Pemberton, J.M. \& MuCullough, D.R. (2001). Bottlenecks, drift and differentiation; the

416 population structure and demographic history of sika deer (Cervus nippon) in the Japanese

417 archipelago. Molecular Ecology 10, 1357-1370.

418 Goudet, J. (2001). FSTAT, A program to estimate and test gene diversities and fixation

419 indices (Version 2.9.3.) http://www2.unil.ch/popgen/softwares/fstat.htm Accessed 16

$420 \quad$ January 2013.

421 Guillemaud, T., Beaumont, M.A., Ciosi, M., Cornuet, J-M., Estoup, A. (2010). Inferring

422 introduction routes of invasive species using approximate Bayesian computation on

423 microsatellite data. Heredity 104, 88-99.

424 Hailstone, M. (2012). The Great British Deer Survey. Deer 16, 12-15.

425 Harris, S., Yalden, D.W. (2008). Mammals of the British Isles Handbook. Mammal Society, 426 Southampton, UK..

427 Harrison, R.G. (1989). Animal mitochondrial DNA as a genetic marker in population and 428 evolutionary biology. Trends in Ecology and Evolution 4, 6-11.

429 Hogg, K., Freeman, M., Burdekin, O., Lennon, J., Reid, N., Dick, J.T.A. (2014). Ards

$430 \quad$ Peninsula muntjac deer (Muntiacus reevesi) survey. Report prepared by the Natural

431 Heritage Research Partnership (NHRP) between Quercus, Queen's University Belfast and

432 the Northern Ireland Environment Agency (NIEA) for the Research and Development

$433 \quad$ Series No. 13/XX. 
434 Hollingsworth, M.L. \& Bailey, J.P. (2000). Evidence for massive clonal growth in the 435 invasive weed Fallopia japonica (Japanese Knotweed). Botanical Journal of the Linnean $436 \quad$ Society 133, 463-472.

437 Holt, C.A., Fuller, R.J. \& Dolman, P.M. (2011). Breeding and post-breeding responses of 438 woodland birds to modification of habitat structure by deer. Biological Conservation 144, $439 \quad 2151-2162$.

440 Jousson, O., Pawlowski, J., Zaninetti, L., Meinesz, A. \& Boudouresque, C.F. (1998)

441 Molecular evidence for the aquarium origin of the green alga Caulerpa taxifolia 442 introduced to the Mediterranean Sea. Marine Ecology Progress Series 172, 275-280.

443 Joys, A., Fuller, R. \& Dolman, P. (2004) Influences of deer browsing, coppice history and 444 standard trees on the growth and development of vegetation structure in coppiced woods 445 in lowland England. Forest Ecology and Management 202, 23-37.

446 Lavergne, S. \& Molofsky, J. (2007). Increased genetic variation and evolutionary potential 447 drive the success of an invasive grass. Proceedings of the National Academy of Sciences USA 104, 3883-3888.

449 Le Page, S., Livermore, R., Cooper, D. \& Taylor, A. (2000). Genetic analysis of a 450 documented population bottleneck: introduced Bennett's wallabies (Macropus rufogriseus 451 rufogriseus) in New Zealand. Molecular Ecology 9, 753-763.

452 Lever, C. (2009). The Naturalised Animals of Britain and Ireland. New Holland Ltd., $453 \quad$ London.

454 Lockwood, J.L., Cassey, P. \& Blackburn, T. (2005) The role of propagule pressure in 455 explaining species invasions. Trends in Ecology and Evolution 20, 223-228.

456 Lockwood, J.L., Cassey, P. \& Blackburn, T.M. (2009) The more you introduce the more you 457 get: the role of colonization pressure and propagule pressure in invasion ecology. Diversity 458 and Distributions 15, 904-910. 
459 Lowe, S., Browne, M., Boudjela,s S. \& De Poorter, M. (2000) 100 of the world's worst

$460 \quad$ invasive alien species: a selection from the global invasive species database. Invasive

$461 \quad$ Species Specialist Group Auckland, New Zealand

462 Luikart, G. \& Curnuet, J-M. (1998). Empirical evaluation of a test for identifying recently

463 bottlenecked populations from allele frequency data. Conservation Biology 12, 228-237.

464 Mayle, B.A.E. ed. (1993). Muntjac Deer; Their Biology, Impact and Management in Britain.

465 Forestry Commission, Farnham and British Deer Society, Trentham.

466 Ohdachi, S., Ishibashi, Y., Iwasa, M. \& Saitoh, T. eds. (2009). The Wild Mammals of Japan.

467 Shoukadoh, Kyoto.

468 van Oosterhout, C., Hutchinson, W.F., Wills, D.P.M. \& Shipley, P. (2004) MICRO-

469 CHECKER: software for identifying and correcting genotyping errors in microsatellite $470 \quad$ data. Molecular Ecology Notes 4, 535-538.

471 Peakall, R. \& Smouse, P.E. (2006). GENALEx 6 Genetic analysis in Excel. Population

472 genetic software for research and teaching. Molecular Ecology Notes 6, 288-295.

473 Piry, A., Luikart, G. \& Cornuet, J.M. (1999). Bottleneck: a computer program for detecting 474 recent reductions in the effective population size using allele frequency data. Journal of $475 \quad$ Heredity 90, 502-503.

476 Provan, J., Murphy, S., Maggs, C.A. (2005). Tracking the invasive history of the green alga 477 Codium fragile ssp. tomentosoides. Molecular Ecology 14, 189-194.

478 Provan, J., Booth, D., Todd, N.P., Beatty, G.E. \& Maggs, C.A. (2008) Tracking biological 479 invasions in space and time: elucidating the invasive history of the green alga Codium $480 \quad$ fragile using old DNA. Diversity and Distributions 14, 343-354.

481 Putman, R.J. \& Moore, N.P. (1998). Impact of deer in lowland Britain on agriculture, forestry 482 and conservation habitats. Mammal Review 28, 141-163. 
483 Raymond, M. \& Rousset, F. (1995). GENEPOP (version 1.2): population genetic software for 484 exact tests and ecumenicism. Journal of Heredity 86, 248-249.

485 Roman, J. \& Darling, J.A. (2007). Paradox lost: genetic diversity and the success of aquatic 486 invasions. Trends in Ecology and Evolution 22, 454-464.

487 Sax, D.F. \& Brown, J.H. (2000) The paradox of invasion. Global Ecology and Biogeography $488 \quad 9,363-371$.

Sclater, P.L. (1875). Notes on rare mammals in the Society's collection. Proceedings of the Scientific Meetings of the Zoological Society of London 421-422

Simberloff, D. (2009). The role of propagule pressure in biological invasions. Annual Review of Ecology, Evolution and Systematics 40, 81-102.

Simberloff, D., Martin, J-L., Genovesi, P., Maris, V., Wardle, D.A., Aronson, J., Courchamp, F., Galil, B., García-Berthou, E., Pascal, M., Pyšek, P., Sousa, R., Tabacchi, E. \& Vila, M. (2013). Impacts of biological invasions: what's what and the way forward. Trends in Ecology and Evolution 28, 58-66.

497 Smith-Jones, C. (2004). Muntjac: Managing an Alien Species. Coch-Y-Bonddu Books, $498 \quad$ Powys.

499 Smouse, P.E. \& Peakall, R. (1999). Spatial autocorrelation analysis of individual multiallele $500 \quad$ and multilocus genetic structure. Heredity 82, 561-573.

501 Stüwe, M. \& Nievergelt, B. (1991). Recovery of alpine ibex from near extinction: the result 502 of effective protection, captive breeding, and reintroductions. Applied Animal Behaviour $503 \quad$ Science 29, 379-387.

504 Tabor, R.C.C. (1998). The oxlip in Britain - is its future in doubt? British Wildlife 10, 92505 101 
506 Taylor, S.S., Jamieson, I.G. \& Armstrong, D.P. (2005). Successful island reintroductions of

507 New Zealand robins and saddlebacks with small numbers of founders. Animal

$508 \quad$ Conservation 8, 415-420.

509 Ward, A., Etherington, T. \& Ewald, J. (2008). Five years of change. Deer 12, 17-20.

510 Weir, B.S. \& Cockerham, C.C. (1984). Estimating F-statistics for the analysis of population 511 structure. Evolution 38, 1358-1370.

512 White, P., Ford, A., Clout, M., Engeman, R., Roy, S. \& Saunders, G. (2008) Alien invasive

513 vertebrates in ecosystems: pattern, process and the social dimension. Wildlife Research 3, $514 \quad 171$.

515 Williams, T., Harris, S., Chapman, N., Wayne, R., Beaumont, M. \& Bruford, M. (1993). A

516 molecular analysis of the introduced Reeves' muntjac in southern England: genetic

517 variation in the mitochondrial genome. in Mayle BAE ed (1993) Muntjac Deer; Their

518 Biology, Impact and Management in Britain. Forestry Commission, Farnham and British

519 Deer Society, Trentham.

520 Wu, H., Meng, K. \& Zhu, G. (2008). Isolation and characterization of microsatellite markers

521 in black muntjac (Muntiacus crinifrons). Molecular Ecology Resources 8, 584-586.

522 Xavier, R., Santos, A., Lima, F. \& Branco, M. (2009). Invasion or invisibility: using genetic

523 and distributional data to investigate the alien or indigenous status of Atlantic populations

524 of the peracarid isopod Stenosoma nadejda (Rezig 1989). Molecular Ecology 18, 3283-

$525 \quad 329$.

526 Zeng, Y., Jiang, Z. \& Li, C. (2007) Genetic variability in relocated Père David's deer

527 (Elaphurus davidianus) populations-Implications to reintroduction program.

$528 \quad$ Conservation Genetics 8, 1051-1059. 
Table 1 Details of populations studied where six or more individuals were analyzed with nuclear microsatellites. $\mathrm{N}-$ number of individuals analysed; $A_{R}$ - allelic richness; $\mathrm{H}_{\mathrm{O}}$ - observed heterozygosity; $\mathrm{H}_{E}$ - expected heterozygosity; $\mathrm{F}_{I S}-$ inbreeding coefficient; $\mathrm{H} 1-\mathrm{H} 7$ - frequency of mitochondrial haplotypes; $\mathrm{H}$ - haplotype diversity.

\begin{tabular}{|c|c|c|c|c|c|c|c|c|c|c|c|c|c|c|c|c|c|}
\hline \multirow[t]{2}{*}{ No } & \multirow[t]{2}{*}{ Name } & \multirow{2}{*}{$\begin{array}{l}\text { Lat } \\
(\mathrm{N})\end{array}$} & \multirow{2}{*}{$\begin{array}{l}\text { Long } \\
\text { (E) }\end{array}$} & \multicolumn{5}{|c|}{ Nuclear microsatellites } & \multicolumn{9}{|c|}{ Mitochondrial D-loop } \\
\hline & & & & $N$ & $A_{R}$ & $H_{O}$ & $H_{E}$ & $F_{I S}$ & $N$ & $\mathrm{H} 1$ & $\mathrm{H} 2$ & $\mathrm{H3}$ & $\mathrm{H} 4$ & $\mathrm{H} 5$ & $\mathrm{H} 6$ & $\mathrm{H} 7$ & $H$ \\
\hline 1 & Kineton, Warwickshire & 52.136 & -1.470 & 12 & 3.723 & 0.563 & 0.675 & $0.173^{\star \star}$ & 12 & - & 11 & 1 & - & - & - & - & 0.167 \\
\hline 2 & Welford, Berkshire & 51.478 & -1.407 & 6 & 3.933 & 0.450 & 0.746 & $0.420^{\star \star \star}$ & 4 & - & 2 & 2 & - & - & - & - & 0.667 \\
\hline 3 & Wytham Wood, Oxfordshire & 51.769 & -1.334 & 10 & 4.099 & 0.663 & 0.764 & $0.140^{*}$ & 10 & - & 7 & 3 & - & - & - & - & 0.467 \\
\hline 4 & Hexton, Bedfordshire & 51.938 & 0.359 & 8 & 4.056 & 0.627 & 0.778 & $0.205^{\star *}$ & 8 & - & - & 1 & 7 & - & - & - & 0.250 \\
\hline 5 & Ickworth Park, Suffolk & 52.218 & 0.649 & 6 & 4.223 & 0.583 & 0.753 & $0.242^{\star *}$ & 2 & - & - & - & 2 & - & - & - & - \\
\hline 6 & Stanta, Suffolk & 52.494 & 0.720 & 9 & 3.768 & 0.500 & 0.700 & $0.298^{\star \star \star}$ & 8 & 5 & - & - & - & 3 & - & - & 0.536 \\
\hline 7 & Shadwell Estate, Norfolk & 53.294 & 0.837 & 14 & 3.826 & 0.537 & 0.718 & $0.259^{\star \star \star}$ & 11 & 9 & - & 1 & 1 & - & - & - & 0.346 \\
\hline 8 & Sennowe Park, Norfolk & 52.773 & 0.912 & 14 & 4.218 & 0.499 & 0.774 & $0.364^{\star * \star}$ & 6 & 2 & 2 & 2 & - & - & - & - & 0.800 \\
\hline 9 & Sandlings, Suffolk & 52.097 & 1.426 & 12 & 5.120 & 0.626 & 0.855 & $0.277^{\star * \star}$ & 8 & 5 & - & - & 3 & - & - & - & 0.536 \\
\hline 10 & Sotterley, Suffolk & 52.404 & 1.625 & 14 & 4.389 & 0.536 & 0.785 & $0.326^{\star * *}$ & 10 & 1 & - & 1 & 7 & 1 & - & - & 0.533 \\
\hline
\end{tabular}


Table 2 Analysis of molecular variance (AMOVA).

\begin{tabular}{llcccc}
\hline Markers & Source of variation & Sum of squares & Variance & \% variation & $P$ \\
\hline Nuclear microsatellites & Among populations & 55.584 & 0.155 & 5.01 & $P<0.001$ \\
& Within populations & 588.655 & 2.943 & 94.99 \\
& & & & & \\
Mitochondrial D-loop & Among populations & 15.206 & 0.190 & 47.00 & $P<0.001$ \\
& Within populations & 14.769 & 0.214 & 53.00 & \\
\hline
\end{tabular}




\section{Figure Legends}

Figure 1 Map showing the distribution of mitochondrial D-loop haplotypes in southeastern England. Inset shows Ireland. Colours refer to haplotypes in Figure 2. Circle size is proportional to the number of samples, with the largest circle representing $N=12$ and the smallest $N=1$. Dots indicate sites for which only microsatellite data were obtained. Numbers refer to Table 1 and Appendix 1. "W" indicates the location of Woburn Abbey.

Figure 2 Median-joining network showing relationships between the seven haplotypes detected by sequencing the mtDNA D-loop region. Circle sizes are approximately proportional to haplotype frequency: smallest circle represents a single individual, largest circle represents 22 individuals. Each dash between haplotypes represents a single mutation. The diamond represents an unsampled ancestral haplotype.

Figure 3 Results of the PCA. The first three axes accounted for $23.17 \%, 20.03 \%$ and $17.59 \%$ respectively of the total variation $(60.78 \%)$. 


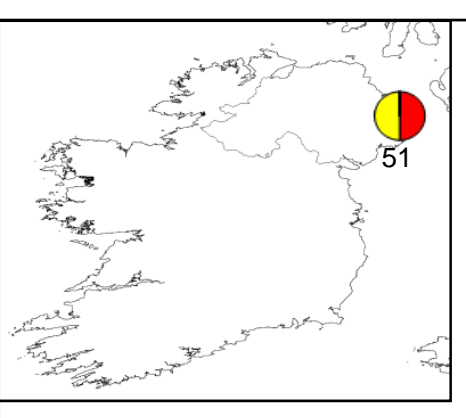

음

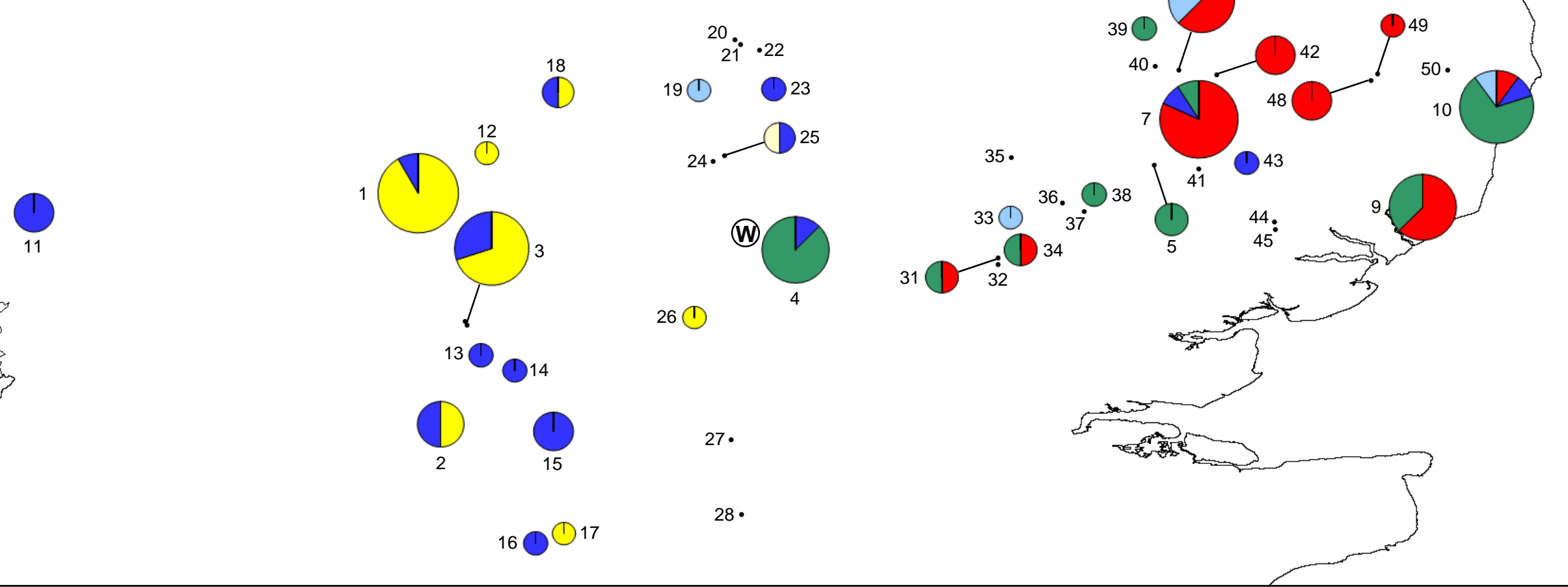




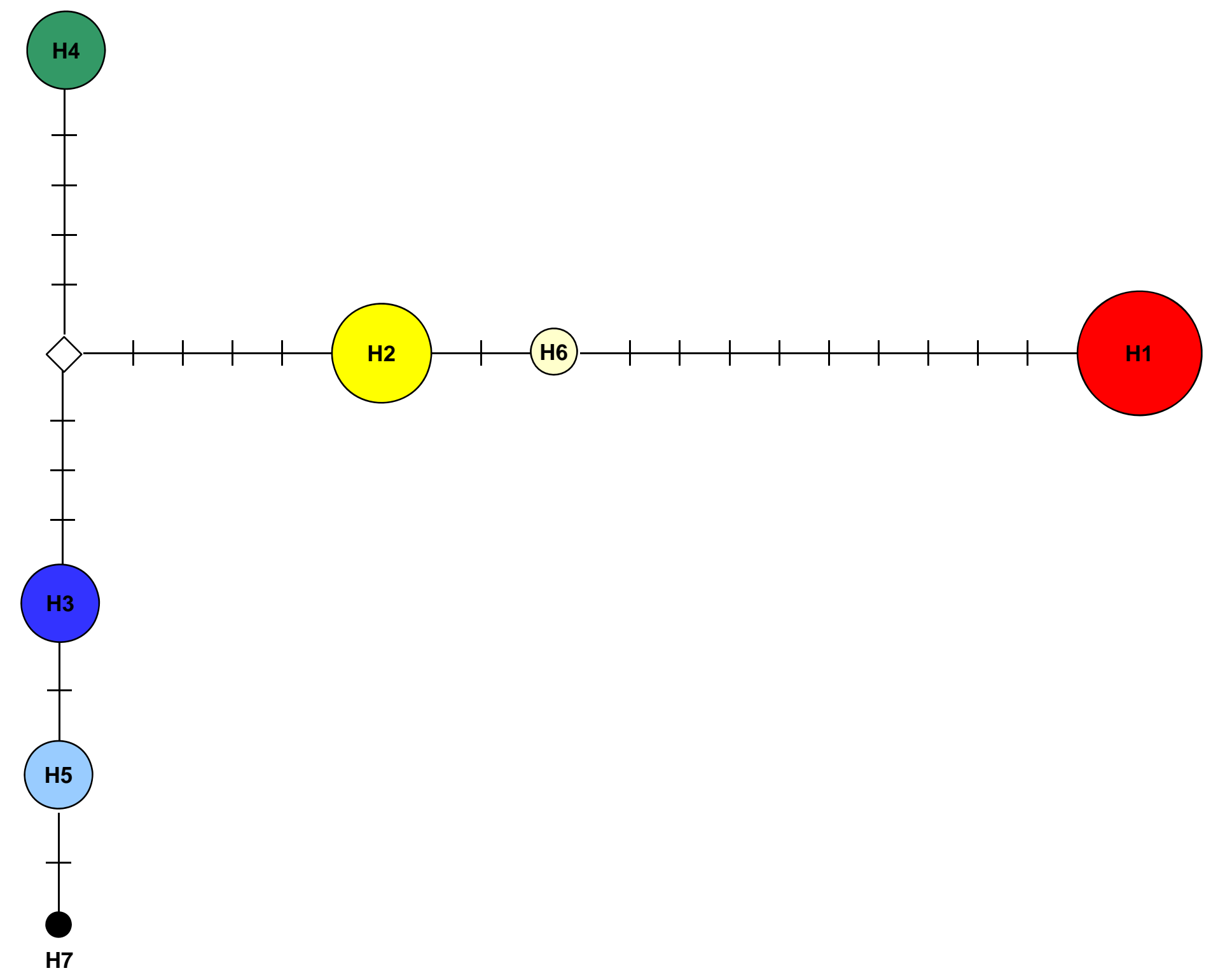




\section{Principal Coordinates (1 vs 2)}

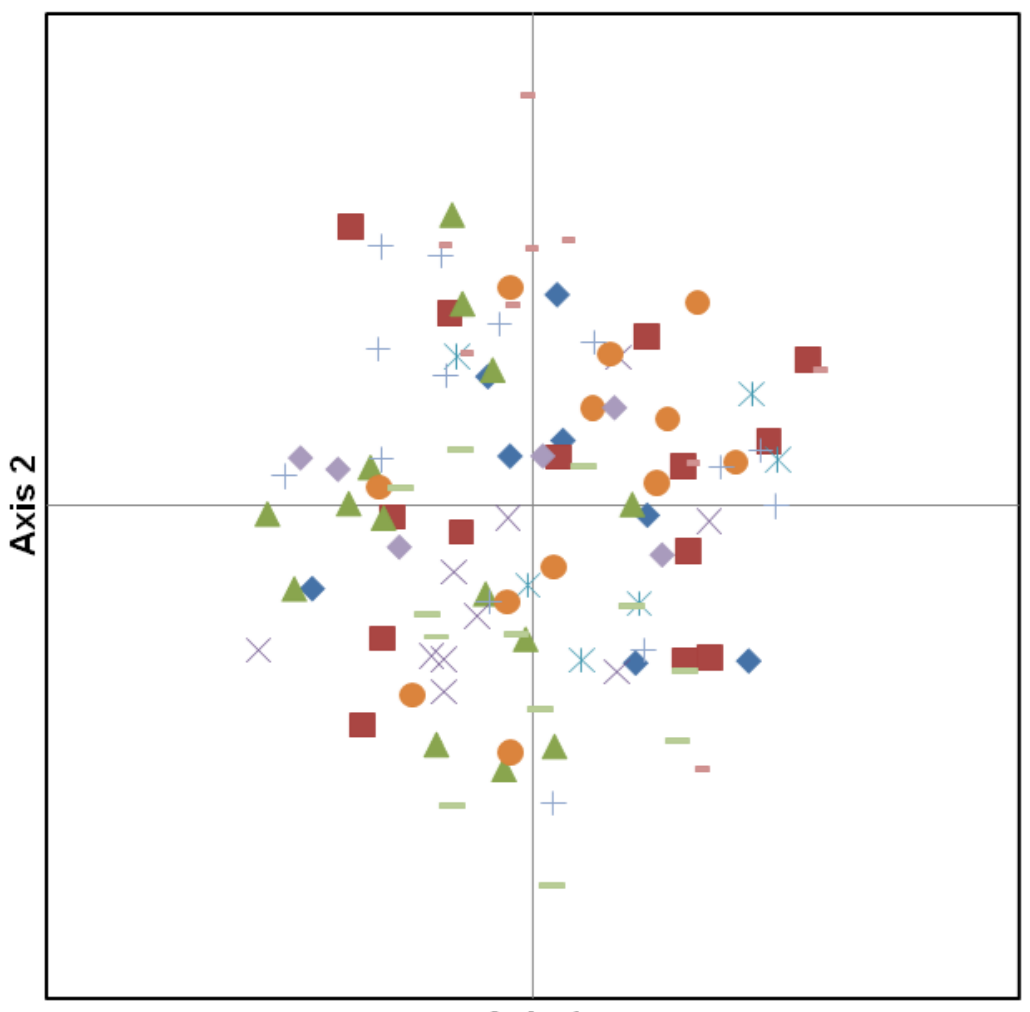

Axis 1

\section{Principal Coordinates (1 vs 3)}

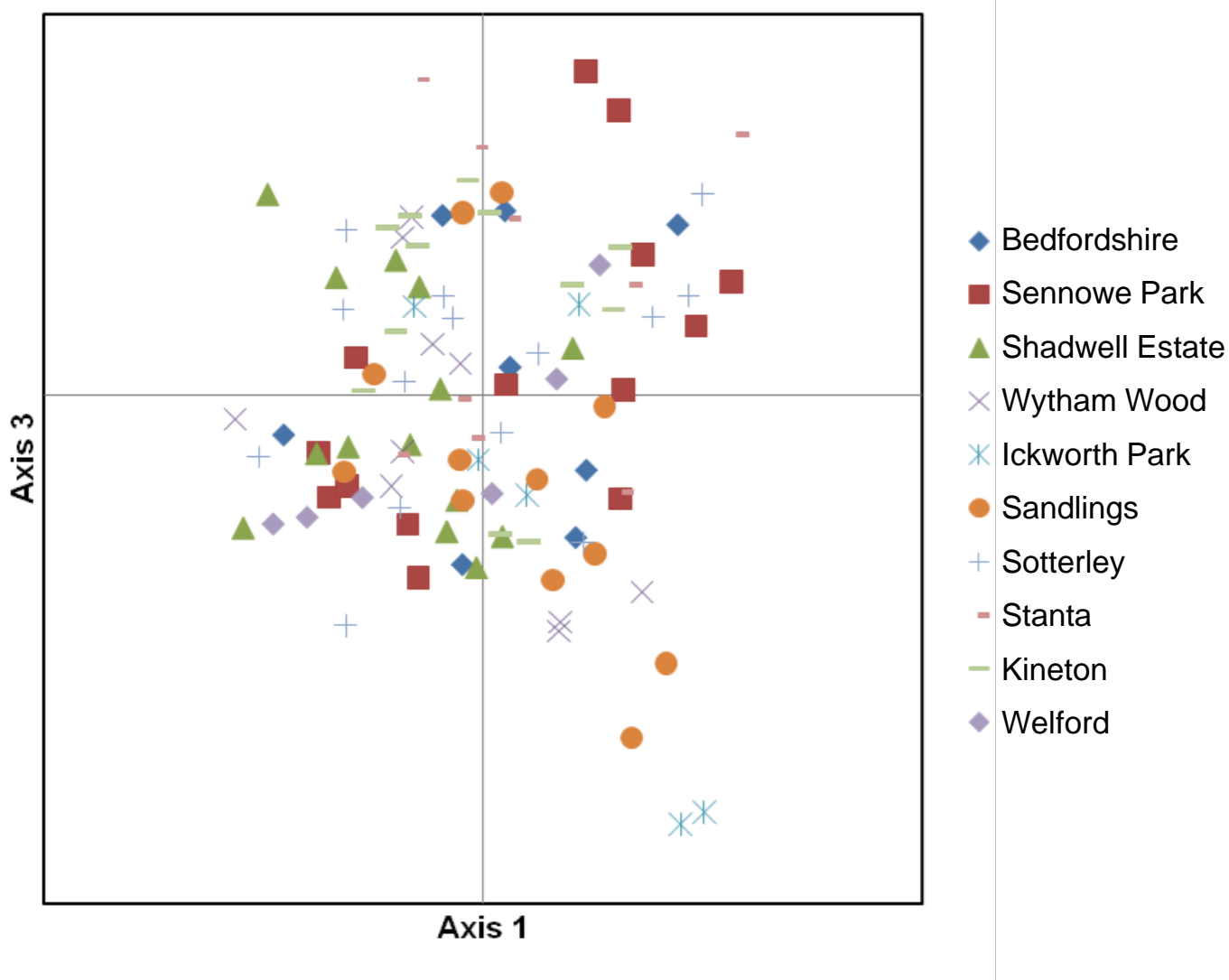


Appendix 1 Samples collected with less than six individuals at a site.

\begin{tabular}{|c|c|c|c|c|c|}
\hline No & Location & Lat $(\mathrm{N})$ & Long (E) & $N_{\text {nuc }}$ & $N_{\mathrm{mt}}$ \\
\hline 11 & Yarkhill, Hertfordshire & 52.082 & -2.573 & 3 & 3 \\
\hline 12 & Shuckburgh Estate, Warwickshire & 52.254 & -1.274 & 2 & 1 \\
\hline 13 & Cothill, Oxfordshire & 51.670 & -1.288 & 1 & 1 \\
\hline 14 & Wittenham Clumps, Oxfordshire & 51.631 & -1.189 & 1 & 1 \\
\hline 15 & Horsemoor Wood, Oxfordshire & 51.456 & -1.078 & 3 & 3 \\
\hline 16 & Lower lanham, Hampshire & 51.128 & -1.131 & 1 & 1 \\
\hline 17 & Alton, Hampshire & 51.157 & -1.051 & 1 & 1 \\
\hline 18 & Old Elvendon, Oxfordshire & 52.426 & -1.068 & 2 & 2 \\
\hline 19 & Broughton Wood, Northamptonshire & 52.432 & -0.661 & 3 & 1 \\
\hline 20 & Finesmade, Northamptonshire & 52.581 & -0.557 & 1 & - \\
\hline 21 & Duddington, Northamptonshire & 52.569 & -0.542 & 1 & - \\
\hline 22 & Apethorpe, Northamptonshire & 52.551 & -0.487 & 2 & - \\
\hline 23 & Fothoringhay, Northamptonshire & 52.437 & -0.444 & 1 & 1 \\
\hline 24 & Forty Acres Wood, Bedfordshire & 52.230 & -0.620 & 1 & - \\
\hline 25 & Great Hayes Wood, Bedfordshire & 52.246 & -0.588 & 4 & 2 \\
\hline 26 & Englefield Estate, Berkshire & 51.430 & -0.569 & 1 & - \\
\hline 27 & Chilworth, Surrey & 51.214 & -0.539 & 1 & - \\
\hline 28 & Bardney, Lincolnshire & 53.215 & -0.308 & 1 & 1 \\
\hline 29 & Woodhall Spa, Lincolnshire & 53.158 & -0.215 & 2 & 2 \\
\hline 30 & Welton Wood, Lincolnshire & 53.202 & 0.197 & 2 & 2 \\
\hline 31 & Quendon, Essex & 51.953 & 0.201 & 2 & 2 \\
\hline 32 & Ugley, Essex & 51.931 & 0.198 & 1 & - \\
\hline 33 & Little Walden, Essex & 52.067 & 0.239 & 1 & 1 \\
\hline 34 & Hamperden End, Essex & 51.980 & 0.263 & 2 & 2 \\
\hline 35 & Lode, Cambridgeshire & 52.241 & 0.239 & 1 & - \\
\hline 36 & Thurlow, Suffolk & 52.108 & 0.384 & 1 & - \\
\hline 37 & Great Thurlew, Suffolk & 52.084 & 0.447 & 1 & - \\
\hline 38 & Thurlow, Suffolk & 52.137 & 0.480 & 1 & 1 \\
\hline 39 & Beachamwell, Norfolk & 52.610 & 0.622 & 1 & 1 \\
\hline 40 & Thetford Forest, Norfolk & 52.506 & 0.651 & 3 & - \\
\hline 41 & Rushbrooke, Suffolk & 52.208 & 0.779 & 2 & - \\
\hline 42 & East Wretham, Norfolk & 52.481 & 0.830 & 3 & 3 \\
\hline 43 & Haughley Park, Suffolk & 52.222 & 0.920 & 1 & 1 \\
\hline 44 & Wolves' Wood, Suffolk & 52.054 & 0.995 & 1 & - \\
\hline 45 & Tom's Wood, Suffolk & 52.033 & 0.997 & 1 & - \\
\hline 46 & Holkham, Norfolk & 52.950 & 0.804 & 4 & 2 \\
\hline 47 & Foxley Wood, Norfolk & 52.765 & 1.036 & 2 & 1 \\
\hline 48 & Shelton, Norfolk & 52.464 & 1.274 & 5 & 3 \\
\hline 49 & Sundy Green, Norfolk & 52.484 & 1.293 & 1 & 1 \\
\hline 50 & Kirby Cane, Norfolk & 52.493 & 1.493 & 2 & - \\
\hline 51 & Mount Stewart, Co. Down & 54.557 & -5.625 & 2 & 2 \\
\hline
\end{tabular}

